\title{
Recombinant Rv0753c Protein of Mycobacterium tuberculosis Induces Apoptosis Through Reactive Oxygen Species-JNK Pathway in Macrophages
}

\author{
Kang-In Lee, Seunga Choi, Han-Gyu Choi, Sintayehu Gurmessa Kebede, Thi Binh Dang, Yong Woo Back, \\ Hye-Soo Park, Hwa-Jung Kim*
}

Department of Microbiology and Medical Science, and Translational Immunology Institute, College of Medicine, Chungnam National University, Daejeon 35015, Republic of Korea

\section{Corresponding}

Hwa-Jung Kim, Professor

Department of Microbiology, College of

Medicine, Chungnam National University,

266 Munwha-ro, Jung-gu, Daejeon 35015,

Republic of Korea

Phone : $+82-42-580-8242$

Fax : $+82-42-585-3686$

E-mail : hjukim@cnu.ac.kr

Received : August 31, 2020

Revised : December 7, 2020

Accepted : December 14, 2020

No potential conflict of interest relevant to this article was reported.

Copyright (C) 2020 Journal of Bacteriology and Virology

(C) This is an Open Access article distributed under the terms of the Creative Commons Attribution Non-Commercial License

(http://creativecommons.org/

license/by-nc/3.0/).
Tuberculosis (TB), caused by Mycobacterium tuberculosis (Mtb), remains one of the most important infectious diseases worldwide. Mtb and its culture filtrates or sonic extracts induce apoptosis in macrophages. However, there is a little known about Mtb components that modulate apoptosis and their regulating mechanism. We identified Rv0753c protein with apoptotic potential through searching the biologic active proteins from the multidimensional fractions of Mtb culture filtrate. Here, we investigated the apoptotic effects of Rv0753c on RAW264.7 cells. The recombinant Rv0753c induced RAW264.7 cells apoptosis in a caspase-9-dependent manner. Dissipation of the mitochondrial transmembrane potential $\left(\Delta \psi_{\mathrm{m}}\right)$, mitochondrial translocation of Bax, and release of cytochrome $c$ from mitochondria were observed in macrophages treated with Rv0753c. Enhanced reactive oxygen species (ROS) production was required for Rv0753c-mediated apoptosis. Furthermore, ROS-mediated JNK activation was major signaling pathway for Rv0753c-induced apoptosis. Moreover, Rv0753c-mediated apoptosis is dependent on TLR4. Altogether, these results suggest that Rv0753C induce apoptosis through ROS-JNK signaling pathway in RAW264.7 cells.

Key Words: Mycobacterium tuberculosis, RAW264.7 cells, Apoptosis, ROS, Rv0753c

\section{INTRODUCTION}

결핵(Tuberculosis)은 결핵균(Mycobacterium tuberculosis)에 의해 발생되는 만성 염증 성 질환이다. 세계보건기구(World Health Organization; WHO)의 2019년 기준, 전 세계 적으로 매년 약 1 천만 건의 신규 환자가 발생하였고, 약 160 만 명이 결핵으로 인하여 사망한 다고 보고하였다 (1). 전 세계 인구의 $1 / 4$ 이 결핵의 원인인 결핵균에 감염된 것으로 추정되 지만 $10 \%$ 미만의 환자만이 증상을 나타내는 결핵을 않고 있다고 보고되었다. 그러나 최근 몇 년 사이 약제내성을 갖는 결핵이 발생됨에 따라서 공중보건 주요 문제로 부상되고 있다 (2).

결핵 감염의 병인은 사람이 호흡을 통해 공기 중 결핵균을 흡입하여 폐의 폐포(alveolar)에 도달하여 시작된다. 폐포의 큰포식세포는 식세포작용을 통해 박테리아를 파괴하거나 성장을 억제하며 결핵균 감염에 대항하는 면역세포로서 숙주 선천면역을 담당한다 (3). 큰포식세포 는 포식-리소좀 융합(phago-lysosome fusion), 활성산소 및 세포자멸사(apoptosis) 활성 화를 비롯한 다수의 살균 기전을 통해 병원균에 대항한다 (4). 숙주의 방어기전으로 선천면 역과 적응면역이 유도되어 세포내 세균을 효과적으로 제거하지만 결핵균은 다양한 기전을 통해 숙주의 보호 면역반응을 회피한다고 보고되었다 (5). 따라서 결핵균의 병원성 기전과 인자를 표적 하는 것은 결핵을 통제하는 더 효과적인 백신과 약의 개발을 가능하게 할 것이다. 
활성산소는 호기성 미생물에서 지속적으로 생성 및 신호전달에 중요한 역할을 함으로써 다양한 병리 생리학적 상태를 조절 한다고 알려 져 있다 (6). 대표적으로 활성산소의 생성은 세포자멸사 과정에서 특징적으로 나타나는 것으로 알려져 있는데 대표적으로 미토콘드리아 의 세포막 전압 붕괴를 유도하여 세포자멸사의 신호 경로에 관여를 한다 $(7,8)$.

병원성 결핵균의 경우 큰포식세포의 세포자멸사 억제 기전을 이용하여 세포내 결핵균 생존에 유리한 환경을 조성하여 큰포식세포에서 사 멸되지 않고 생존하는 것으로 알려져 있다 (9). 반면에 약독화된 결핵균은 병원성 결핵균과 비교하여 큰포식세포의 세포자멸사를 더 많이 유도한다고 보고되어 있다 (10). 이처럼 결핵균의 병원성과 큰포식세포의 세포자멸사와의 상관관계가 분명히 있다고 추측할 수 있지만 정확한 작용기전은 아직도 불분명하다. 결핵균에 의한 큰포식세포의 세포자멸사 기전을 밝히는 것은 결핵균 감염에 대한 병인 기전을 이 해하는데 도움이 될 것이다.

세포자멸사는 숙주의 방어기전으로 병원체를 제거하거나 병원체가 포함된 자멸사체(apoptotic body)를 다른 포식세포에 제시하여 면역 방어 기전을 활성화 한다 (8). 반면 미코박테리아는 숙주세포의 세포자멸사 기전에 필요한 인자들을 억제하여 세포 내의 복제를 촉진하거 나, 오히려 세포자멸사를 전략적으로 유도하여 큰포식세포로부터 방출되어 감염되지 않는 세포를 감염시키는 병인 기전 중의 하나로 알 려져 있다 $(11,12)$. 따라서 세포자멸사 조절에 관여하는 박테리아의 성분을 확인하고 특성을 분석하는 것은 미코박테리아의 병인 기전 과 숙주-기생체 간 상호작용 이해를 향상시키는데 크게 기여할 것이다. 현재 몇몇 미코박테리아 단백질이 큰포식세포의 세포 사멸을 조절 하는 것으로 보고되고 있다. Early secreted protein antigen ESAT6 (Rv3763) (13), 19-kDa lipoproteins LpqH (Rv3763) (14)는 toll-like receptor (TLR) 2 신호 전달 경로를 통해 숙주 세포의 사멸을 유도하며, 다른 미코박테리아 Rv3261 (15) 단백질과 MAV2052 (16) 단백질이 TLR4 신호 전달 경로를 통해 큰포식세포의 세포자멸사를 유도한다고 보고되었다.

결핵균 배양액과 초음파추출액의 다차원분획에서 생물학적인 활성단백을 탐색하는 과정에서 세포자멸사를 유도하는 Rv0753c 항원을 발굴하였고, 이에 본 연구는 Rv0753c의 세포자멸사 유도기전을 분석하였다. 재조합 Rv0753c 단백질은 caspase-9 의존적 방식으로 큰 포식세포의 세포자멸사를 유도 하였다. 또한, 활성산소와 매개된 JNK 신호전달의 활성화가 주요 신호 경로였다. 마지막으로, Rv0753C 이 TLR4 신호를 통해 세포자멸사를 유도함을 입증하였다.

\section{MATERIALS AND METHODS}

\section{Rv0753c 단백질의 정제}

단백질 항원 정제는 Choi 등 (17)의 방법에 준하여 실시하였다. 재조합 단백질 발현을 위해 결핵균 genomic DNA로부터 단백질의 해당 유전자를 (forward) 5'- CATATGACCACACAGATTTCACATTTC-3', (reverse) 5'- AAGCTTACTCATTGTGGGGATGACGAA-3', primer 를 사용하여 증폭하였고, 생산된 유전자 산물을 발현벡터인 pET22b(+) (Novagen, Madison, WI, USA)에 클로닝하였다. Rv0753c 단백의 유전자가 클로닝된 발현벡터를 형질전환시킨 대장균을 배양한 후, $1 \mathrm{mM}$ isopropyl $\beta$-D-1-thiogalactopyranoside (IPTG; ELPIS-Biotech, Daejeon, South Korea)를 첨가하여 단백질 발현을 유도 하였다. 배양된 균은 원심분리를 통하여 수집하였고, 20 $\mathrm{mM}$ Tris-HCL ( $\mathrm{pH}$ 8.0), $0.5 \mathrm{M} \mathrm{NaCl}, 5 \mathrm{mM}$ inmidazole, 그리고 $1 \mathrm{mM}$ phenylmethylsulfonyl fluoride (PMSF; Sigma, St. Louis, MO)에 부유하여 초음파 파쇄하였다. 발현확인을 통하여 확인된 재조합 단백질의 정제는 nikel-nitrilotiacetic acid (NI-NTA, Qiagen, Valencia, CA) agarose chromatography 를 이용하여 제조회사의 방법에 준하여 정제하였다. 최종적으로 정제한 단백질은 sodium dodecyl sulfate-polyacrylamide gel electrophoresis (SDS-PAGE)에 전기영동 하여, Coomassie brilliant blue (Invitrogen, Carlsbad, CA, USA)를 이용한 염색과 anti-His antibody (Santa Cruz, CA)를 이용한 immunoblot을 통하여 분석하였다.

\section{$\mathrm{Rv} 0753 \mathrm{c}$ 단백질 농도 측정}

단백질의 농도는 bovine serum albumin (BSA)를 표준으로 하여 Micro BCA protein assay kit (Pierce, Rockford, IL, USA)를 이용하 여 제조회사의 방법에 준하여 ELSIA plate reader로 $562 \mathrm{~nm}$ 에서 OD (optical density) 값을 측정하였다.

세포주의 배양

본 실험에 사용된 마우스 유래 큰포식세포주인 RAW264.7 세포(ATCC, SC-6003)는 ATCC (Manassas, VA, USA)으로부터 분양 받아 사용하였다. RAW264.7 세포배양은 Dulbecco's modified Eagle's medium (DMEM; BioWhittaker, Lonaz, USA)에 10\% fetal 
bovine serum (FBS) 및 100 unit/ml penicillin/streptomycin (Welgene, Daegu, South Korea)을 첨가하였고, 37 $\mathrm{C}, 5 \% \mathrm{CO}$ 조건 의 배양기에서 계대 배양하였다.

\section{DNA fragmentation assay}

DNA fragmentation assay는 Sohn 등 (18)의 방법에 따라 RAW264.7 세포의 세포자멸사를 DNA fragmentation assay (Cell Death

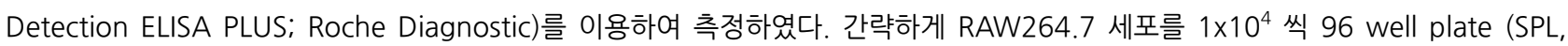
Pocheon, South Korea)의 각 well에 분주한 후 16시간 동안 배양한 후 $10 \mu \mathrm{g} / \mathrm{ml}$ 의 농도로 처리하여 24시간을 배양하였다. 배양 후 $1500 \mathrm{rpm}$ 에서 10 분간 원심분리 후 상등액을 제거하고. Lysis buffer로 상온에서 30 분간 반응시킨 후 $1500 \mathrm{rpm}$ 에서 10 분간 원심분 리 후 상등액 $20 \mu \ell$ 를 코팅이 되어있는 plate로 옮겼다. $80 \mu \ell$ 의 면역시약(anti-histone-biotin $4 \mu \ell$, anti-DNA-POD $4 \mu \ell$, incubation buffer $72 \mu l)$ 을 각 well 에 첨가 후 상온에서 2시간 반응시켰다. 상등액을 제거 후 250-300 $\mu$ incubation buffer로 5회 세척하였다. $100 \mu \ell \mathrm{ABTS}$ 용액을 각 well 에 첨가 후 20분간 반응시킨 후 $(\mathrm{OD}=450 \mathrm{~nm})$ 로 측정하였다.

항체 및 시약

Anti-caspase-3, anti-caspase-9, anti-PARP, anti- $\alpha$-tubulin, VDAC, anti-ERK1/2, anti-p38, anti-JNK, anti-phosphorylated ERK1/2, anti-phosphorylated p38, anti-phosphorylated JNK, 그리고 anti- $\beta$-actin 항체들을 Cell Signaling (Beverly, MA, USA)에 서 구매하였다. Z-VAD-fmk, N-acetyl-cysteine (NAC), horseradish peroxidase-conjugated anti-rabbit lgG, anti-mouse lgG, p38 mitogen-activated protein kinase (MAPK; SB203580), specific inhibitors of ERK (U0126), 그리고 JNK (SP600125) 항체 들은 Calbiochem (San Diego, CA, USA)에서 구매하였다. Cytochrome $c$ 항체는 BD Pharmingen (San Diego, CA, USA)에서 구입 하였다. His-probe, anti-Bax (6A7), 그리고 $\alpha$-tubulin 항체는 Santa Cruz Biotechnology (Santa Cruz, CA, USA)에서 구입하였다. 3,3'-Dihexyloxacarbocyanine ( $\mathrm{DiOC}_{6}$ ) 그리고 Dichlorodihydrofluorescein diacetate (DCFH-DA)는 Molecular Probes (Eugene, OR, USA)에서 구입하였다.

\section{Annexin V-Propidium iodide (PI) 염색 방법을 이용한 세포자멸사 분석}

세포자멸사 분석은 PaiK 등 (19)의 방법에 준하여 실시하였다. RAW264.7 세포를 $5 \times 10^{4}$ cells씩 12 well plate의 각 well에 분주한 후 16 시간 동안 배양한 후 단백을 $10 \mu \mathrm{g} / \mathrm{ml}$ 의 농도로 처리하여 24시간 배양하였다. 세포를 수집한 후 1X binding buffer로 2회 세척하였 다. Annexin V-FITC $100 \mu \ell$ 를 상온의 암실에서 30분간 염색한 후 propidium iodide (PI)-PE $200 \mu \ell$ 를 첨가하였다. 염색된 Annexin V-FITC와 PI는 FACS Canto II system, BD Biosciences (San Diego, CA, USA)을 이용하여 세포자멸사가 유도된 세포는 Annexin V-FITC에 양성으로 녹색으로 염색되고, 세포괴사가 유도되면 PI에 양성으로 적색으로 염색되는 것을 FlowJo 7.6 software, Tree Star Inc (Ashland, OR, USA)로 분석하였다

\section{미토콘드리아 세포막 전압(Mitochondrial transmembrane potential, $\Delta \Psi \mathrm{m}$ ) 붕괴 측정}

미토콘드리아 세포막 전압 붕괴는 DiOC 6 (Molecular Probes) 염색을 이용하여 분석하였다. RAW264.7 세포를 $5 \times 10^{4}$ cells씩 12 well plate의 각 well에 분주한 후 16시간 동안 배양한 후 단백을 $10 \mu \mathrm{g} / \mathrm{ml}$ 의 농도로 처리하여 24시간 배양하여 세포를 수집한 후 PBS로 1회 세척하였다. $10 \mathrm{nM}$ 의 $\mathrm{DiOC}_{6}$ 를 첨가하고 상온의 암실에서 30분간 반응시켰다. PBS로 3회 세척하고 PBS $300 \mu$ 로 재부유 시킨 후 즉시 FACS Canto II system (BD Biosciences)을 이용하여 미토콘드리아 세포막 전압 붕괴를 측정하고 FlowJo 7.6 software (Tree Star Inc)로 분석하였다. 미토콘드리아 세포막 전압 붕괴 측정은 Whang 등 (20)의 방법에 준하여 실시하였다.

\section{세포 내 활성산소 생성 측정}

세포 내 활성산소의 생성 수준은 Dichlorodihydrofluorescein diacetate (DCFH-DA) assay (Molecular Probes) 분석법을 이용하여 측 정하였다. RAW264.7 세포를 $5 \times 10^{4}$ cells씩 12 well plate의 각 well에 분주한 후 16 시간 배양한 후 단백을 $10 \mu \mathrm{g} / \mathrm{ml}$ 의 농도로 처리하여 24시간 배양하여 세포를 1,500 rpm으로 5분간 원심분리 후 PBS로 1회 세척하고 DCFH-DA $10 \mu \mathrm{M}$ 로 상온에서 30분 동안 염색하였다. 
PBS로 2회 세척한 후 PBS $300 \mu$ 로 재부유 하여 FACS Canto II system (BD Biosciences)를 이용해 활성산소가 생성되는 수준을 분석하였다.

\section{웨스턴 블롯 분석(Western blot analysis)}

웨스턴 블롯 분석은 Choi 등 (21)의 방법에 준하여 실시하였다. Caspase, MAPKs의 활성도와 미토콘드리아 단백질의 위치 변화를 확인 하기 위해 세포단백 추출액을 수집하고 단백질 양을 정량 한 후 sodium dodecyl sulfate-polyacrylamide gel electrophoresis (SDS-PAGE)로 전기영동을 수행하였다. 전기영동으로 분리된 단백질을 Polyvinyl difluoride membrane (PVDF, Milipore corporation, Billerica, MA, USA)에 1시간 전사(transfer)하였고, 5\% skim milk가 포함된 Tris-buffered saline tween (TBST; 20 $\mathrm{mM}$ tris, $137 \mathrm{mM}$ sodium chloride, $0.1 \%$ Tween-20)으로 1시간 동안 상온에서 blocking하였다. 1차 항체 반응은 각각의 항체를 $4^{\circ} \mathrm{C}$ 에서 16시간 반응시켰으며 TBST로 10분씩 5회 세척하였다. 2차 항체 반응은 Horseradish peroxidase가 표지 된 anti-mouse lgG, anti-rabbit lgG항체를 5\% skim milk가 포함된 TBST로 2,000배 희석하여 상온에서 1시간 반응시킨 후 TBST로 10분씩 5회 세척하였 다. 단백질 발현 밴드의 검출은 chemiluminescence's assay kit (ECL; Millipore corporation, Billerica, MA, USA)로 발색시켰다.

통계학적 처리

모든 실험은 독립적으로 3번 반복하였으며, 실험을 통해 얻어진 결과들은 평균 및 표준오차로 나타내었다. 통계적 유의성은 통계프로그 램(GraphPad Prism Software, version 4.03; GraphPad Software, San Diego, CA)으로 Tukey's multiple 방법을 이용하여 검증하 였다. $p$ 값이 0.05 이하 또는 0.001 이하를 기준으로 통계적 유의성을 검증하였다.

\section{RESULTS}

\section{RAW264.7 세포에 대한 Rv0753c 항원의 세포자멸사 유도 효과}

E. coli에서 발현된 Rv0753c 재조합 단백질은 Ni-NTA affinity chromatography를 이용하여 정제하였고, SDS-PAGE와 항-His 항체로 웨스턴 블롯을 실시한 결과 정제된 단백질은 약 $53.5 \mathrm{kDa}$ 에 주요 단일 밴드로 관찰되었다(Fig. 1a). FACS 분석 결과 Rv0753c가 처리된 RAW264.7 세포가 처리되지 않은 세포와 비교하여 농도 의존적인 방식으로 유의한 세포자멸사를 유발하였다(Fig. 1b). Staurosporine (STS)는 양성 대조군으로 사용되었다. 미코박테리아 대조군 단백질로 강력한 면역 반응성을 가진 antigen 85 complex (Ag85)를 사용 하였으나 유의한 수준의 세포자멸사를 유도하지 않았다. 또한 DNA 단편화 분석(DNA fragmentation assay) 결과 Rv0753c가 처리된 세포가 처리되지 않은 세포나 Ag85가 처리된 세포와 비교하여 RAW264.7 세포에서 유의하게 높은 수준의 세포자멸사를 유발하였다 (Fig. 1C). 세포 사멸 경로 중의 하나로 미토콘드리아에 의한 세포 사멸과 관련된 caspase-9 및 caspase-3를 포함한 caspase의 활성화 에 의해 시작 된다는 것은 잘 알려져 있다 (15). Rv0753c는 RAW264.7 세포에서 절단된 형태의 caspase-3, caspase-9 과 poly ADP ribose polymerase (PARP)를 유의미하게 증가시켰다(Fig. 1d). 반면에 pan-caspase 억제제 z-VAD-fmk를 이용한 전처리에서는 Rv0753c 유도 DNA 단편화가 현저하게 감소하였다(Fig. 1e). 이러한 결과는 Rv0753c가 RAW264.7 세포에서 caspase-9 의존성 세포 자멸사를 유도한다는 것을 시사한다.

\section{Rv0753c 항원 처리 후 미토콘드리아 의존적 세포자멸사 유도 확인}

미토콘드리아는 미토콘드리아 의존적 세포사멸 경로의 활성화를 초래하는 내인성 세포사멸(Intrinsic apoptosis) 경로를 조절하는데 핵 심적인 역할을 하기 때문에 미토콘드리아의 세포막 전압(Mitochondrial transmembrane potential, $\Delta \psi \mathrm{m}$ ) 유지관리는 살아있는 세포 의 기본 기능으로 알려져 있다 (22). 따라서 Rv0753c의 자극이 미토콘드리아의 $\Delta \psi \mathrm{m}$ 손실에 어떤 영향을 미치는지 조사하였다. Rv0753c에 의한 RAW264.7 세포의 자극은 Ag85로 처리된 세포나 미처리된 세포에 비해 형광 강도가 현저히 감소하는 것을 확인할 수 있었고, 이는 미토콘드리아의 $\Delta \Psi \mathrm{m}$ 손실이 증가함을 보여준다(Fig. 2a). 다음으로 Rv0753c의 자극이 큰포식세포에서 cytochrome c (Cyt c) 방출 및 Bax 전위(translocation)에 영향을 미칠 수 있는지 확인하였다. 웨스턴 블롯 분석 결과 Rv0753c로 자극된 RAW264.7 세포의 미토콘드리아 분획에서 Bax의 단백질 수치가 유의미하게 증가한 것을 확인할 수 있었고, Cyt c 발현 수준은 미토콘드리아 분획에 서 감소하고 세포기질(cytosol) 분획에서 증가하는 것으로 조사되었다(Fig. 2b). 이러한 결과로부터 RAW264.7 세포에서 Rv0753c 매 개 세포자멸사가 Cyt c 방출 및 $\mathrm{Bax}$ 전위과 관련이 있다는 것을 알 수 있었다. 
(a)

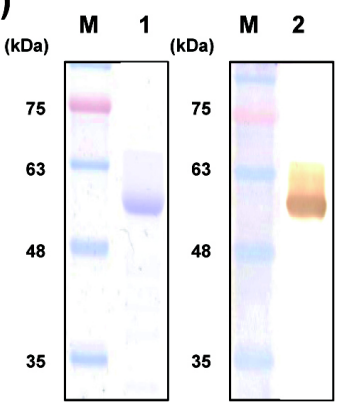

(c)

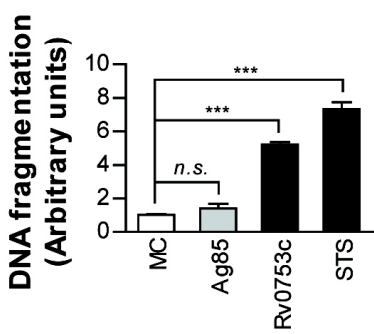

(b)

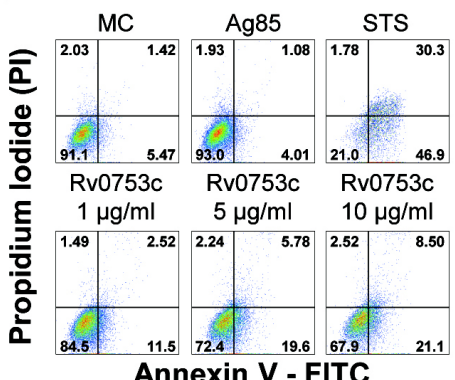

(d)

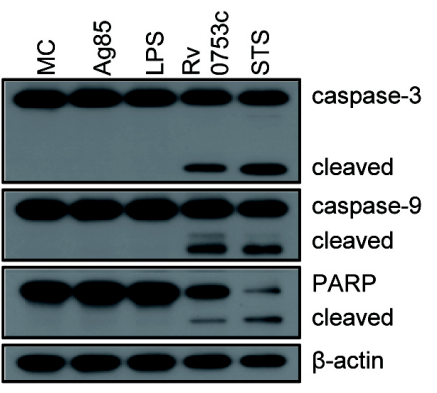

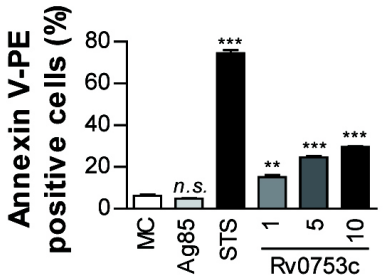

(e)

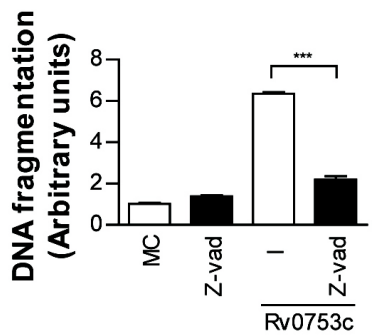

Fig. 1. Rv0753c induces caspase-dependent apoptosis of RAW264.7 cells. (a) The purified $10 \mu \mathrm{g} / \mathrm{mL}$ of Rv0753c protein was subjected to SDS-PAGE and western blot analysis using a mouse anti-His antibody. (b) The apoptosis of RAW264.7 cells treated with Ag85 $(10 \mu \mathrm{g} / \mathrm{mL})$, STS $(50 \mathrm{nM})$, and Rv0753c $(1,5$, and $10 \mu \mathrm{g} / \mathrm{mL})$, and the cells were harvested after $24 \mathrm{~h}$. The macrophage cells were then stained with annexin V/PI. The percentage of cells in each quadrant is indicated. Data are expressed as the mean \pm SD of at least three experiments. $* p<0.05, * * p<0.01, * * * p<0.001$ cells treated with media (MC, medium control) compared to cells treated with antigens. n.s., no significant difference. (c) The DNA fragmentation of RAW264.7 cells incubated with Ag85 $(10 \mu \mathrm{g} / \mathrm{mL})$, STS $(50 \mathrm{nM})$, and Rv0753c $(10 \mu \mathrm{g} / \mathrm{mL})$ for $24 \mathrm{~h}$ were put to ELISA assay using kits for determining the levels of DNA fragmentation. Data are expressed as the mean \pm SD of at least three experiments. $* * p<0.01, * * * p<0.001$ cells treated with media (MC, medium control) compared to cells treated with antigens. (d) Immunoblotting analysis of caspase-3 and -9, and PARP in RAW264.7 cells treated with Ag85 (10 $\mathrm{mg} / \mathrm{mL})$, LPS $(100 \mathrm{ng} / \mathrm{mL}), \operatorname{Rv} 0753 \mathrm{c}(10 \mathrm{\mu g} / \mathrm{mL})$, and STS $(50 \mathrm{nM})$ for $24 \mathrm{~h}$. The cell lysates were separated by SDS-PAGE, followed by immunoblotting analysis using antibodies against caspase-3, caspase-9, PARP, and $\beta$-actin. (e) RAW264.7 cells were incubated with Rv0753c $(10 \mu \mathrm{g} / \mathrm{mL})$ in the presence or absence of z-VAD-fmk $(50 \mu \mathrm{M})$ for $24 \mathrm{~h}$. The amounts of DNA fragmentation were then measured by ELISA. The results are expressed as the mean \pm SD of three independent experiments. $* * * p<0.001$ cells incubated with Rv0753c only compared to those incubated with Rv0753c + z-VAD-fmk.

(a)

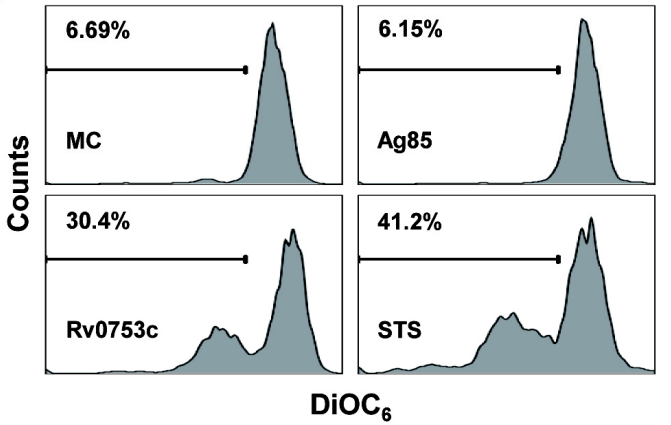

(b)

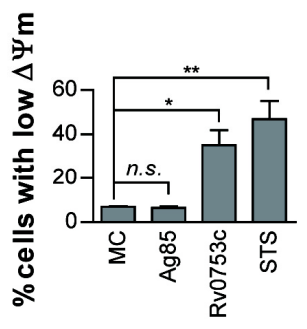

Fig. 2. Rv0753c induces $\Delta \Psi_{\mathrm{m}}$ collapse of RAW264.7 cells. (a) RAW264.7 cells were incubated with Ag85 (10 $\mathrm{mg} / \mathrm{mL}$ ), STS (50 $\mathrm{nM})$, and Rv0753c $(10 \mu \mathrm{g} / \mathrm{mL})$ for $24 \mathrm{~h}$. The macrophage cells were then stained with DiOC $6(10 \mathrm{nM})$. A loss of $\Delta \psi \mathrm{m}$ was assessed by flow cytometry and the percentage of positive cells is shown in each panel. The data are shown as the mean \pm SD of three independent experiments. $* p<0.05$, and $* * p<0.01$ media control (MC) cells compared to cells treated with antigens. n.S., no significant difference. (b) RAW264.7 cells were treated with or without Rv0753c (10 $\mu \mathrm{g} / \mathrm{mL})$ for $24 \mathrm{~h}$. The levels of Bax and cytochrome c (Cyt c) in the cytosolic (Cyto) and mitochondrial (Mito) fractions were measured by immunoblotting. The expression of VDAC and $\alpha$-tubulin were used as the loading controls of the mitochondrial and cytosolic fractions. The results are representative of three independent experiments. 
(a)

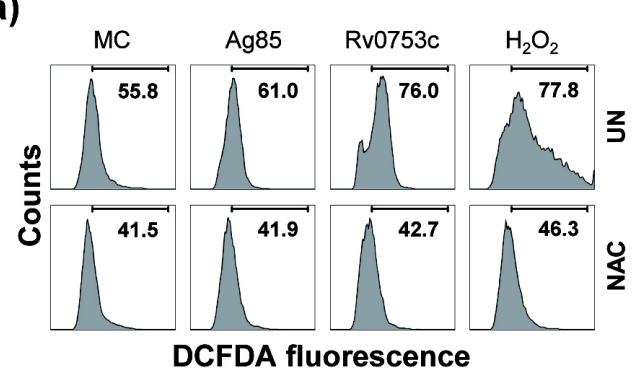

(b)

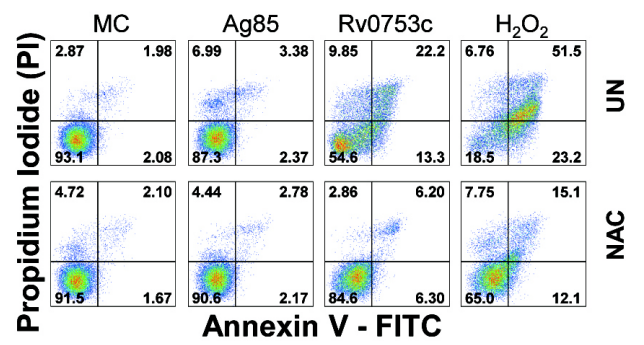

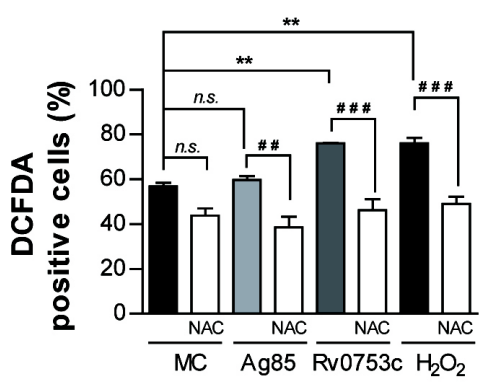

(c)

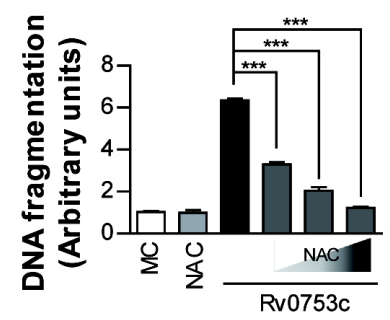

Fig. 3. Rv0753c induces apoptosis through ROS production. (a) RAW264.7 cells were treated with Rv0753c (10 $\mathrm{\mu g} / \mathrm{mL}), \mathrm{Ag} 85$ $(10 \mathrm{\mu g} / \mathrm{mL})$, and H2O2 (500 nM) in the presence or absence of NAC $(10 \mathrm{mM})$ for $24 \mathrm{~h}$. The ROS levels were measured by flow cytometry after DCFDA $(10 \mu \mathrm{m})$ treatment. The percentage of proliferating cells is shown in each panel. The data are shown as the mean \pm SD of three independent experiments. $* \star p<0.01 \mathrm{MC}$ compared to cells treated with antigens, \#\#p $<0.01$ and $\# \# \# p<0.001$ compared each antigen to the NAC pre-treated cells. n.S., no significant difference. (b) The apoptosis of RAW264.7 cells treated with the antigens in the presence or absence of NAC (10 mM) was measured by flow cytometry using Annexin V/PI staining. The macrophage cells were then stained with annexin V/PI. The percentage of cells in each quadrant is indicated. (c) RAW264.7 cells were pre-treated with NAC (5, 10, and $20 \mathrm{mM})$ for $1 \mathrm{~h}$ prior to incubation with Rv0753c (10 $\mu \mathrm{g} / \mathrm{mL}$ ) for $24 \mathrm{~h}$. The quantity of DNA fragmentation were then measured by ELISA. Data are presented as the mean \pm SD of three experiments. $* * * p<0.001$ compared to Rv0753c alone with each NAC pre-treated cells.

\section{Rv0753c 항원 자극 후 생성되는 활성산소(reactive oxygen species, ROS) 확인}

활성산소는 큰포식세포의 세포자멸사에서 중요한 역할을 한다 $(23,24)$. Rv0753c에 의해 유도된 RAW264.7 세포의 세포자멸사에 활 성산소가 관련되어 있는지 확인하기 위해 DCFH-DA 형광 염색 방법을 사용하여 활성산소 생산 정도를 평가하였다. Rv0753c의 자극은 미처리 세포에 비해 RAW264.7 세포에서 DCFH-DA의 유의미한 증가를 유도하였다. 활성산소 스캐빈저(scavenger)로 잘 알려진 $\mathrm{N}$-acetylcysteine (NAC)을 이용한 전처리는 $\mathrm{Ag} 85, \mathrm{H}_{2} \mathrm{O}_{2}$, 그리고 Rv0753-매개 활성산소의 생산을 현저하게 억제하였다(Fig. 3a). 더 나아가 NAC을 이용한 RAW264.7 세포의 전처리는 Rv0753c에 의해 유도된 세포자멸사를 감소 시켰고(Fig. 3b), 또한 Rv0753c 매개 DNA 단편화를 현저하게 감소시켰다(Fig. 3c). 이러한 데이터는 Rv0753c가 활성산소의 생산을 통해 RAW264.7 세포의 세포자멸사를 유도한다는 것을 시사한다.

\section{Rv0753c 항원의 자극에 의한 RAW264.7 세포의 MAPK 활성}

활성산소의 세포 내 농축은 MAPK 활성을 유도하고, MAPK는 RAW264.7 세포의 세포자멸사를 유도하는데 중요한 역할을 하는 신호전 달인자로 알려져 있다 $(15,16)$. 따라서 Rv0753c가 활성산소의 생산을 통해 MAPK 활성화를 유발했는지 조사하였다. 다양한 시점에 걸 쳐 Rv0753c 자극 후 RAW264.7 세포의 ERK1/2, p38 그리고 JNK의 활성화를 분석하였다. Rv0753c를 자극 후 15분 뒤에 ERK1/2, p38 그리고 JNK의 인산화가 가장 강하게 나타나는 것을 확인할 수 있었다(Fig. 4a). 다음으로 Rv0753c가 유도한 MAPK 활성화가 세포 내 활성산소의 생산과 관련되어 있는지 확인하였다. NAC 전처리는 RAW264.7 세포에서 용량 의존적 방식으로 JNK의 인산화를 감소시 켰지만 ERK1/2 및 p38의 인산화는 감소시키지 않았다(Fig. 4b). 게다가 JNK 특정 억제제가 Rv0753c로 자극된 RAW264.7 세포에서 세포자멸사를 감소시키는 반면 ERK1/2 및 p38 특정 억제제는 세포자멸사를 억제하지 않는 것이 확인되었다(Fig. 4c). 이러한 결과는 활 성산소를 매개한 JNK 신호전달의 활성화가 RAW264.7 세포에서 Rv0753c가 유도하는 세포자멸사와 관련되어 있음을 보여준다. 
(a)

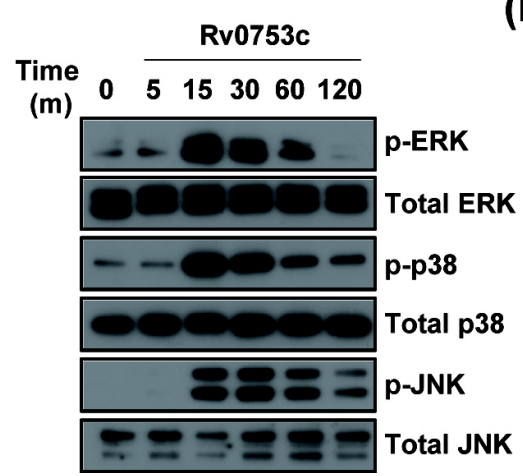

(c)

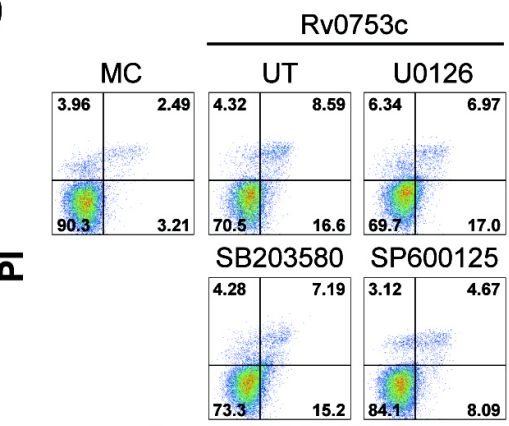

Annexin V - FITC (b)

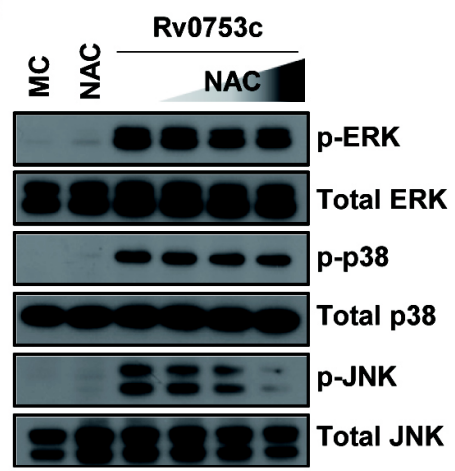

Fig. 4. Rv0753c-mediated JNK activation is associated with ROS production and apoptosis. (a) For MAPKs activation analysis, RAW264.7 cells were treated with $10 \mu \mathrm{g} / \mathrm{ml}$ Rv0753c for the indicated times. The cell lysates were analysed using an immunoblot analysis was performed using specific antibodies. The images show a representative example of three independent experiments showing similar results. (b) RAW264.7 cells were pre-incubated with NAC (5, 10, and 20 mM) for 1 $\mathrm{h}$ and then treated with Rv0753c $(10 \mu \mathrm{g} / \mathrm{ml})$ for $15 \mathrm{~min}$. The cell lysates were analysed using an immunoblot analysis was performed using specific antibodies. The images show a representative example of three independent experiments showing similar results. (c) RAW264.7 cells were incubated with ERK inhibitor (U0126), p38 inhibitor (SB203580), and JNK inhibitor (SP600125) $10 \mu \mathrm{M}$ for $1 \mathrm{~h}$ prior to the treatment with Rv0753c $(10 \mu \mathrm{g} / \mathrm{mL})$, or with UT (DMSO; vehicle control with Rv0753c). After $24 \mathrm{~h}$, screening for the induction of apoptosis was performed using Annexin V/PI staining. Flow cytometric histograms are represented as the mean \pm SD of three independent experiments. $* * * p<0.001$ Rv0753c alone compared to cells incubated with Rv0753c co-treated with MAPK inhibitors. n.S., no significant difference.

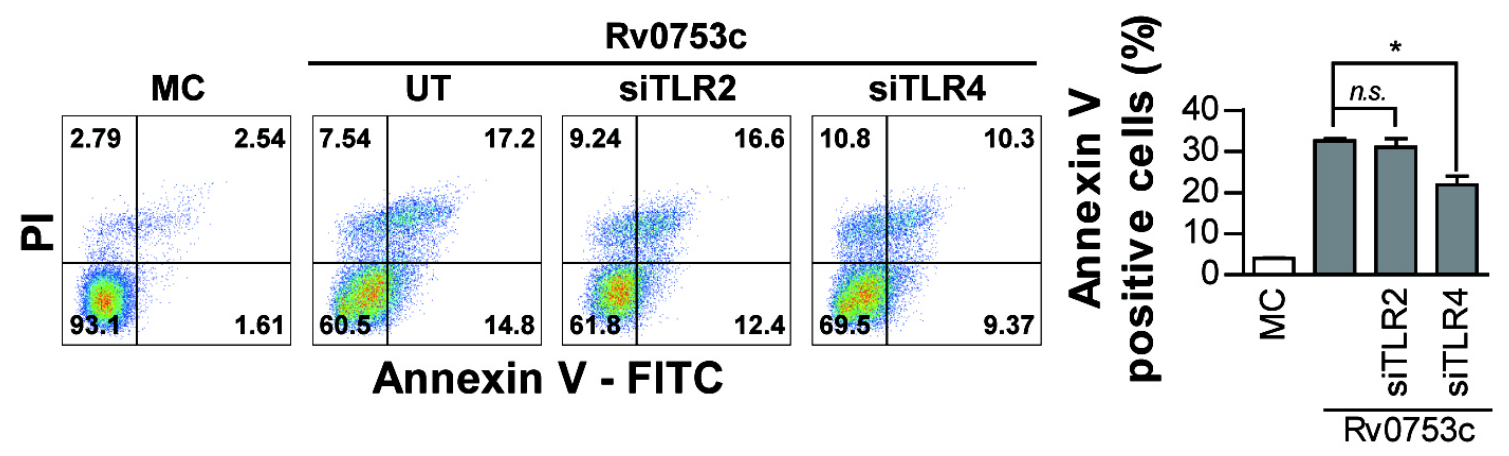

Fig. 5. Rv0753c induces apoptosis through TLR4 in RAW264.7 cells. RAW264.7 cells were transfected with control siRNA (200 $\mathrm{nM})$, TLR2 siRNA (200 nM), and TLR4 siRNA (200 nM) and incubated for $6 \mathrm{~h}$. The transfected RAW264.7 cells stimulated with Rv0753c $(10 \mu \mathrm{g} / \mathrm{mL})$ for $24 \mathrm{~h}$. Apoptotic cells were assessed by flow cytometry and the percentage of annexin V/PI positive cells is shown in each panel. Data are the mean \pm SD from three independent experiments. $* p<0.05$ Rv0753c alone compared to cells incubated with Rv0753c, transfected siRNA TLR4 cells, and Rv0753c with transfected siRNA TLR2 cells n.S., no significant difference. 
TLR4를 통한 세포자멸사 활성

다양한 결핵균 단백질들이 TLR의 인식을 통해 큰포식세포의 세포자멸사를 유도하는 것으로 보고 되고 있다 $(25,26)$. 그러므로 저자들은 Rv0753c의 자극을 통해 TLR 수용체와 세포자멸사 사이의 관계를 확인하였다. RAW264.7 세포는 RV0753c 자극 이전에 TLR2 siRNA 와 TLR4 siRNA 로 형질주입(transfection) 처리를 하였다. Rv0753c로 유도된 세포자멸사는 TLR4 siRNA가 형질주입된 RAW264.7 세 포에서 형질주입 되지 않은 대조군 세포와 비교하여 현저하게 억제되었다. 그러나 TLR2 SiRNA가 형질주입된 RAW264.7 세포의 세포자 멸사는 억제되지 않았다(Fig. 5). 이러한 데이터는 Rv0753c에 의한 세포자멸사가 TLR4와 관련이 있음을 시사한다.

\section{DISCUSSION}

큰포식세포는 결핵균을 포식하여 사멸시키는 세포인 동시에 결핵균이 생존하는 저장소 역할도 한다 $(27,28)$. 따라서 큰포식세포의 효과 적인 활성화 및 조절은 결핵균을 제거하는데 아주 중요하다. 결핵균은 숙주세포의 죽음을 조절하는 것은 물론 항균성 면역의 유도나 억제 를 담당하는 다양한 성분을 포함하고 있다. 저자들은 이전 연구를 통해 큰포식세포의 세포사멸을 유도하는 여러 미코박테리아 단백질을 보고하였다 $(7,8,15,16)$. 이들 항원들은 결핵균 배양액과 초음파 추출물의 다차원 분획화(multidimensional fractionation)를 통해 발굴되었다. 본 연구에서는 마우스 큰포식세포주인 RAW264.7 세포를 대상으로 최근 발굴한 결핵균 단백항원인 Rv0753c에 대한 세포 자멸사 유도를 관찰하였고 그 결과 미토콘드리아 경로를 통해 큰포식세포의 세포자멸사를 유도하는 것을 입증하였다.

Rv0753c (MmsA)는 수지상 세포(dendritic cell)의 활성화를 유도하고 Th1 세포 면역반응을 촉진한다 (29). 잠복결핵감염과 활성동 폐 결핵 환자의 말초혈액을 Rv0753c로 자극하면 항원특이적 $\mathrm{CD} 4^{+} \mathrm{T}$ 세포와 $\mathrm{CD} 8^{+} \mathrm{T}$ 세포 반응이 유도되었다 (30). 저자들은 이전 연구를 통 해 비결핵 및 결핵 환자에 강한 항체 면역 반응을 나타내는 MAV2054 단백질이 큰포식세포의 미토콘드리아를 표적하여 세포자멸사를 유 도한다는 것을 확인하였다 (8). 따라서 본 연구에서 발굴된 Rv0753c 항원 또한 강한 면역 반응을 나타내기에 세포의 죽음을 유도할 수 있 다는 가능성을 갖고 큰포식세포에서 어떤 세포사멸의 특징을 나타내는지 조사를 하였다. Rv0753c 항원은 caspase-9/-3를 활성화 시키는 내인성 경로를 통해 큰포식세포의 세포자멸사를 유도하는 것을 확인하였다. 미토콘드리아는 세포사멸의 주요 사건들이 발생하는 중심 세 포기관이다 (31). 저자들은 이전에 결핵균 배양액에서 확보된 heparin-binding hemagglutinin (HBHA) 항원이 큰포식세포의 미토콘드 리아 의존적 세포자멸사를 유도한다는 것을 확인하였다 (7). Rv0753c 항원으로 자극된 큰포식세포는 미토콘드리아에 Bax의 전위를 유도 하고 미토콘드리아의 $\Delta \Psi \mathrm{m}$ 손실을 유도하여 결과적으로 cytochrome $\mathrm{c}$ 를 방출시킨다. 세포질에서 미토콘드리아 구획으로 $\mathrm{Bax}$ 가 전위되 면 미토콘드리아의 $\Delta \psi \mathrm{m}$ 의 손실이 촉진되고 미토콘드리아 구획에서 cytochrome c와 세포자멸사 유도인자인 apoptosis-inducing factor (AIF)가 방출된다 (31). 저자들은 이전 연구를 통해 Bax가 미토콘드리아로 전위되고 cytochrome c가 방출되는 것이 결핵균 항원 인 Rv3261로 유도된 큰포식세포의 세포자멸사에 관여한다고 보고 하였다 (15). 활성산소는 주로 미토콘드리아에서 생성되고 $\Delta \Psi \mathrm{m}$ 을 조절하여 최종적으로 cytochrome c를 방출하여 세포자멸사를 유도한다 (32). 본 연구를 통해 큰포식세포에서 Rv0753c에 유도된 활성 산소의 생산이 $\mathrm{NAC}$ 의 전처리에 의해 상당히 감소되었음을 관찰하였다. 이러한 결과는 Rv0753c가 활성산소의 생성 및 $\triangle \Psi \mathrm{m}$ 붕괴를 통 해 큰포식세포의 세포자멸사를 유도함을 나타내며, 이 두 가지 요인이 Rv0753c 유도 세포자멸사에서 필수적인 역할을 함을 시사한다.

여러 미코박테리아 단백질은 큰포식세포를 자극하여 다양한 신호 경로를 통해 염증촉진성(pro-inflammatory) 또는 항염증성(antiinflammatory cytokines) 사이토카인 분비를 유도한다 $(2,33)$. 이러한 경로들 중 MAPK는 대부분 결핵균과 숙주 면역 세포의 구성 요 소와 반응하여 활성화되며, 또한 활성산소의 발생을 통한 큰포식세포의 세포자멸사에도 관여한다 $(8,16)$. 활성산소는 박테리아에 대한 숙주 방어 기전에 의해 생성되며, 주로 미토콘드리아에서 생성되어 높은 수준으로 유지되면서 큰포식세포의 세포자멸사를 유발한다 $(7$, 15). 본 연구에서 Rv0753c는 MAPK 경로를 통해 큰포식세포를 활성화 하였다. 흥미롭게도, Rv0753c 매개 MAPK 경로 중 ERK 1/2와 $\mathrm{p} 38$ 의 활성화는 활성산소 스캐빈저인 NAC의 전처리에 의해 억제되지 않았지만 JNK 활성화는 현저하게 억제되는 것으로 밝혀졌다. 더 욱이 Rv0753c에 유도된 세포자멸사 또한 JNK 억제제에 의해 유의하게 억제 되어있지만 ERK 1/2, p38 억제제에 의해 억제되지 않았으 며, 이는 활성산소가 큰포식세포에서 Rv0753C 유도 세포자멸사에 중요한 역할을 함을 나타낸다. 이러한 결과는 활성산소 매개 JNK 활성 신호 경로가 큰포식세포에서 Rv0753c 매개 세포자멸사에 관여 함을 시사한다.

몇몇 미코박테리아 단백질은 TLR2 및 TLR4와 상호작용을 통해 큰포식세포의 활성화나 세포자멸사를 유도한다. Early secreted antigenic target of 6-kDa (ESAT-6) 단백질은 TLR2를 통해 caspase-9 그리고 caspase-3 의존적 큰포식세포의 세포자멸사를 유도한 다 (13). 또한, MAV2052 단백은 TLR4 의존 경로를 통해 활성산소의 생성, $\Delta \Psi \mathrm{m}$ 손실 및 caspase-3의 활성화를 유발하여 큰포식세포 
의 세포자멸사를 유도한다 (16). 본 연구에서 TLR4가 녹다운(knock down)된 큰포식세포에서 Rv0753c에 유도된 세포자멸사가 감소되 는 것을 확인하였고, 이는 Rv0753c가 TLR4의 인식을 통해 큰포식세포의 세포자멸사가 유도됨을 시사한다.

결론적으로 본 연구에서는 결핵균 정제단백항원인 Rv0753C 항원이 큰포식세포의 TLR4를 통해 활성산소 및 JNK 신호전달을 활성화시켜 내인성 경로를 통해 큰포식세포의 세포자멸사가 유도됨을 확인하였다. 앞으로 Rv0753c 유전자를 과발현하는 돌연변이 균주를 제작하여 균주의 감염 동안 Rv0753c가 큰포식세포의 세포자멸사를 유도하는 기능적 역할을 갖는지를 평가하는 후속 연구가 필요하다고 생각한다.

\section{ACKNOWLEDGEMENTS}

This study was supported by the Basic Science Research Program through the National Research Foundation of Korea (NRF) funded by the Ministry of Science, ICT, and Future Planning (2020R1A2C1008826).

\section{DECLARATION OF CONFLICTING INTERESTS}

The authors declare that they have no known competing financial interests or personal relationships that could have influenced the work reported in this paper.

\section{REFERENCES}

1) WHO guidelines on tuberculosis infection prevention and control: 2019 update. WHO Guidelines Approved by the Guidelines Review Committee. Geneva 2019.

2) Park HS, Back YW, Shin KW, Bae HS, Lee KI, Choi HG, et al. Mycobacterium tuberculosis Rv3463 induces mycobactericidal activity in macrophages by enhancing phagolysosomal fusion and exhibits therapeutic potential. $S C i$ Rep 2019:9:4246.

3) Guo Y, Deng Y, Huang Z, Luo Q, Peng Y, Chen J, et al. EBP50 induces apoptosis in macrophages by upregulating nitric oxide production to eliminate intracellular Mycobacterium tuberculosis. Sci Rep 2016:6:18961.

4) Meng CY, Liang X, Wei K, Yang YR. Enantioselective Ir-Catalyzed Allylic Alkylation of Racemic Allylic Alcohols with Malonates. Org Lett 2019:21:840-3.

5) Parandhaman DK, Narayanan S. Cell death paradigms in the pathogenesis of Mycobacterium tuberculosis infection. Front Cell Infect Microbio/2014;4:31.

6) Aslan M, Ozben T. Oxidants in receptor tyrosine kinase signal transduction pathways. Antioxid Redox Signal 2003:5:781-8.

7) Sohn H, Kim JS, Shin SJ, Kim K, Won CJ, Kim WS, et al. Targeting of Mycobacterium tuberculosis heparin-binding hemagglutinin to mitochondria in macrophages. PLOS Pathog 2011;7:e1002435.

8) Lee KI, Whang J, Choi HG, Son YJ, Jeon HS, Back YW, et al. Mycobacterium avium MAV2054 protein induces macrophage apoptosis by targeting mitochondria and reduces intracellular bacterial growth. SC Rep 2016:6:37804

9) Butler RE, Brodin P, Jang J, Jang MS, Robertson BD, Gicquel B, et al. The balance of apoptotic and necrotic cell death in Mycobacterium tuberculosis infected macrophages is not dependent on bacterial virulence. PloS one 2012;7:e47573.

10) Fratazzi C, Arbeit RD, Carini C, Balcewicz-Sablinska MK, Keane J, Kornfeld H, et al. Macrophage apoptosis in mycobacterial infections. J Leukoc Bio/ 1999;66:763-4. 
11) Zhang J, Jiang R, Takayama $H$, Tanaka $Y$. Survival of virulent Mycobacterium tuberculosis involves preventing apoptosis induced by $\mathrm{BCl}-2$ upregulation and release resulting from necrosis in $\mathrm{J774}$ macrophages. Microbio/ Immunol 2005:49:845-52.

12) Awuh JA, Flo TH. Author Correction: Molecular basis of mycobacterial survival in macrophages. Cell Mol Life Sci 2018:75:161.

13) Lin J, Chang Q, Dai X, Liu D, Jiang Y, Dai Y. Early secreted antigenic target of 6-kDa of Mycobacterium tuberculosis promotes caspase-9/caspase-3-mediated apoptosis in macrophages. Mol Cell Biochem 2019;457:179-89.

14) Sánchez A, Espinosa P, García T, Mancilla R. The 19 kDa Mycobacterium tuberculosis lipoprotein (LpqH) induces macrophage apoptosis through extrinsic and intrinsic pathways: a role for the mitochondrial apoptosis-inducing factor. Clin Dev Immuno/2012:2012:950503.

15) Lee KI, Choi S, Choi HG, Kebede SG, Dang TB, Back YW, et al. Recombinant Rv3261 protein of Mycobacterium tuberculosis induces apoptosis through a mitochondrion-dependent pathway in macrophages and inhibits intracellular bacterial growth. Cell Immuno/2020;354:104145.

16) Lee KI, Choi HG, Son YJ, Whang J, Kim K, Jeon HS, et al. Mycobacterium avium MAV2052 protein induces apoptosis in murine macrophage cells through Toll-like receptor 4. Apoptosis 2016:21:459-72.

17) Choi HG, Choi S, Back YW, Park HS, Bae HS, Choi CH, et al. Mycobacterium tuberculosis Rv2882c Protein Induces Activation of Macrophages through TLR4 and Exhibits Vaccine Potential. PloS One 2016;11:e0164458.

18) Sohn H, Kim K, Lee KS, Choi HG, Lee KI, Shin AR, et al. Lithium inhibits growth of intracellular Mycobacterium kansasii through enhancement of macrophage apoptosis. J Microbio/2014;52:299-306.

19) Paik S, Choi S, Lee KI, Back YW, Son YJ, Jo EK, et al. Mycobacterium tuberculosis acyl carrier protein inhibits macrophage apoptotic death by modulating the reactive oxygen species/c-Jun $\mathrm{N}$-terminal kinase pathway. Microbes Infect 2019:21:40-9.

20) Whang J, Back YW, Lee KI, Fujiwara N, Paik S, Choi CH, et al. Mycobacterium abscessus glycopeptidolipids inhibit macrophage apoptosis and bacterial spreading by targeting mitochondrial cyclophilin D. Cell Death Dis 2017;8:e3012.

21) Choi S, Choi HG, Shin KW, Back YW, Park HS, Lee JH, et al. Mycobacterium tuberculosis Protein Rv3841 Activates Dendritic Cells and Contributes to a T Helper 1 Immune Response. J Immunol Res 2018;2018:3525302.

22) Kroemer G. Mitochondrial control of apoptosis: an overview. Biochem Soc Symp 1999;66:1-15.

23) Lim YJ, Choi HH, Choi JA, Jeong JA, Cho SN, Lee JH, et al. Mycobacterium kansasirinduced death of murine macrophages involves endoplasmic reticulum stress responses mediated by reactive oxygen species generation or calpain activation. Apoptosis 2013;18:150-9.

24) Azad N, lyer AKV, Manosroi A, Wang L, Rojanasakul Y. Superoxide-mediated proteasomal degradation of Bcl-2 determines cell susceptibility to $\mathrm{Cr}(\mathrm{VI})$-induced apoptosis. Carcinogenesis 2008;29:1538-45.

25) López M, Sly LM, Luu Y, Young D, Cooper H, Reiner NE. The 19-kDa Mycobacterium tuberculosis protein induces macrophage apoptosis through Toll-like receptor-2. J Immuno/2003;170:2409-16.

26) Grover S, Sharma T, Singh Y, Kohli S, P M, Singh A, et al. The PGRS Domain of Mycobacterium tuberculosis PE_PGRS Protein Rv0297 Is Involved in Endoplasmic Reticulum Stress-Mediated Apoptosis through Toll-Like Receptor 4. mBio 2018;9:e01017-8. 
27) Rodrigues MF, Barsante MM, Alves CCS, Souza MA, Ferreira AP, Amarante-Mendes GP, et al. Apoptosis of macrophages during pulmonary Mycobacterium bovis infection: correlation with intracellular bacillary load and cytokine levels. Immunology 2009;128:e691-9.

28) Mahamed D, Boulle M, Ganga $Y$, Mc Arthur C, Skroch S, Oom L, et al. Intracellular growth of Mycobacterium tuberculosis after macrophage cell death leads to serial killing of host cells. Elife 2017;6:e22028.

29) Kim JS, Kim WS, Choi HH, Kim HM, Kwon KW, Han SJ, et al. Mycobacterium tuberculosis MmsA, a novel immunostimulatory antigen, induces dendritic cell activation and promotes Th1 cell-type immune responses. Cell Immuno/2015;298:115-25.

30) Pathakumari B, Devasundaram S, Maddineni P, Raja A. Rv2204c, Rv0753C and Rv0009 antigens specific T cell responses in latent and active TB - a flow cytometry-based analysis. Int J Med Microbio/2018:308:297-305.

31) Green DR, Reed JC. Mitochondria and apoptosis. Science 1998;281:1309-12.

32) Fleury C, Mignotte B, Vayssière JL. Mitochondrial reactive oxygen species in cell death signaling. Biochimie 2002;84:131-41.

33) Kim K, Sohn H, Kim JS, Choi HG, Byun EH, Lee KI, et al. Mycobacterium tuberculosis Rv0652 stimulates production of tumour necrosis factor and monocytes chemoattractant protein-1 in macrophages through the Toll-like receptor 4 pathway. Immunology 2012:136:231-40. 